\title{
SEASONAL OCCURRENCE OF MOSQUITO AND ITS INFECTIVITY OF JAPANESE B ENCEPHALITIS VIRUS IN OKAYAMA CITY 194?, RELATIONSHIP BETWEEN THE GRADE OF EPIDEMIC AND THE INFECTIVITY OF MOSQUITO.
}

\author{
By Tokushiro MITAMURA, Masami KITAOKA and Miki IMAI \\ National Institute of Health of Japan \\ (Received for publication, April 9, 1950)
}

Seasonal fluctuation of mosquito collected in nature and biting experiment with the mosquito to see if and how high the mosquito in nature was infectious of Japanese B encephalitis virus in Okayama City have been studied during the period between May and early December 1942. The similar investigations have been repeatedly made since the summer in $1937(1,2,3,4,5$,).

\section{Method}

The technique employed for this purpose has been given in the report for the year 1938 (2). The collection of mosquito was made by means of netting the mosquito resting on the wall of a certain room specially chosen for this purpose at the Club-Hous, Okayama Medical College for an hour 3.00-4.00 p. m. almost every day as possible as the two appointed assistants could. The collection was without delay sent to Tokyo for studies on the seasonal appearance of various species of mosquito and for the biting experiment with the mosquito on mice to find the carrier of Japanese B encephalitis virus. The another same experiment was carried out in Okayama during the period from July 7 to September 4 .

\section{Experiment I. Seasonal Fluctuation of Mosquito in Nature}

The actual number and various species of mosquitoes collected each for five days during the period from May to December 1942 were shown in Table 1. The total number of the day on which mosquito was actually collected were 177 . The total number of mosquito collected were 6.033 among which 3,899 (64.62\%) belonged to Culex pipiens var. pallens, 1952 (32.38\%) Cu!ex tritaeniorhynchus. These two species of mosquito were predominant $(97 \%)$ in number of the whole mosquitoes collected. Among the remaining mosquitoes $83(1.38 \%)$ belonged to Aedes togoi, 17 (0.28\%) Aedes albopictus, $40(0.66 \%)$ Anopheles hyrcanus sinensis, 4 (0.07\%) Culex bitaeniorhynchus, 6 (0.1\%) Culex annulus, $3(0.05 \%)$ Culex rubithoracis, 18 (0.3\%) Armigeres obturbans, 3 (0.05\%) Culex orientalis and $8(0.14 \%)$ Lutzia fuscana.

The daily averaged number of the mosquitoes collected and its classification each for the five day period described above were shown in Figure 1 in order to make it easily comprehensive the seasonal fluctuation of mosquito in Okayama.

As a whole the mosquito seemed to begin to increase in number at the end of May 
1942 and reached its sharp top peak at the middle of July and then decreased in number by the end of the same month and gradually diminished thereafter. In other words, the -top peak so-called "Yamada's peak" of the curve in this year much earlier than those in the years 1938, 39 and 40, and later than that in 1941. Another small peaks of mosquito were observed during the period of August, September and October, which have been already reported.

As regards the each species of mosquito, Culex pipiens var. pallens started to increase in number at the end of May and then decreased in number and reached to its top peak at the end of June and in early July, however, it was still found in December in the winter season. Culex tritaeniorhynchus appeared suddenly towards the end of June, and made a sharp top peak at the middle of July and then fell in number rapidly. It disappeared completely in early October. The so-called "Yamada's peak" in 1942 consisted of chiefly (more than 90 per cent in number of the mosquito in peak) this species of mosquito. This result is more like that obtained in 1938 and quite different from those in the years 1939, 1940 and 1941.

Anopheles hyrcanus sinensis was found in this year chiefly during the later days in July and in early September, Aedes togoi between the middle of June to July and in early September while other species, namely, Aedes albopictus, Culex bitaeniorhynchus, Culex annulus and others were found during the period from the end of July to early August. In the close observation on the seasonal occurrence of the mosquito of each species especially of Culex pipiens var. pallens collected in nature 1942, certain periodicity was found in increase and decrease in number of the mosquito. It might be attributed to a periodical emergence of the mosquito.

\section{Infectivity of the Mosquito Collected in Nature of Japanese B ENCEPHALITIS ViRUS.}

After counting and classiification of the mosquitoes collected at the Club-House mentioned above they were put in a cage for the biting experiment on mice. The experiment has been performed to see if any mosquito may have capable to infect mice with the Jepanese B encephalitis virus. All the alive mosquitoes collected in nature during the period May to December were devided into 18 groups. Each group was put in one cage. Then 18 cages were set for the biting experiment. As a whole 181 mice have been actually bitten by the mosquito and 515 mosquitoes have actually fed on mice. That is to say that 2.8 mosquitoes have bitten a mouse on an average.

All the mice which had developed any questionable symptoms or been found dead of unknown cause were autopsied. The emulsion of the brain removed from the mice mentioned above was intracerebrally inoculated into mice. The blind passage was made for few generations to try to isolate Japanese $B$ encephalitis virus. But none has proved of any positive result.

Another collection of mosquito during the period of July to September at the Nurse dormitory supplied us another 47 cages and additional collection of mosquito at our dormitory 3 cages. The biting experiment was carried out in the similar way mentioned 
above. As a whole 6,314 mosquitoes have bitten actually mice and 517 mice have been bitten actually by mosquito. In other words 12 mosquitoes have been fed on a mouse on an average. Those mosquitoes collected at the two dormitories mentioned above chiefly Culex tritaeniorhynchus, some Culex pipiens var. pallens, and a few Anopheles hyrcanus sinensis and the other common mosquitoes in summer season.

Among the 517 mice bitten by the mosquito, one mouse which was bitten by 46 Culex tritaeniorhynchus collected at the nurse dormitory in the evening of August 11, has developed the cerebral symptoms 10 days after being bitten. Hypersensitiveness with its ruffled hair and convulsions also were observed. The emulsion prepared from the mouse brain was intracerebrally inoculated into mice. They showed a typical encephalitis symptom 5 days after injection. The histological findings of the brain tissue of these mice proved encephalitis on peri-vascular cuff, infiltration of glia cells, degeneration of nervous cells and so on.

Another three mice which have been bitten by mosquitoes collected at our dormitory on August 9, 15, and 19 respectively have not shown a typical encephalitis symptom but the mice of the second generation which had been inoculated with the emulsion of the brain from the mice showed a typical encephalitis symptom. The first mouse among those three was known having been bitten by 2 and the third one by 15 Culex tritaeniorhynchus and the second mouse was by 17 mosquitoes of the same species together with two mosquitoes which have not been exactly identified.

Four strains of virus were recovered from the mice bitten by the mosquito collected in nature in 1942. They could not been cultivated on ordinary bacteriological culture media and were filtrable through Berkefeld filter. They were identified by the cross neutralizing test as well as cross protection test to the "Calinina" strain a representative strain of Japanese B encephalitis virus. The mouse which was used for the biting experiment was bought from the mouse dealer. Then the attention should be paid to avoid the contamination of the virus from the mouse itself because the healthy looking mouse was spontaneously infected with Japanese B encephalitis virus as pointed out by Kawamura (6) and by us (9). Anyway the disease which developed in the mouse 10 days after having been bitten by the mosquito collected on August 11 might be due to the Japanese $B$ encephalitis virus transmitted by mosquito.

One Japanese B encephalitis case were reported on August 21. He died on September 2 under diagnosis of encephalitis. This diagnosis was confirmed by histological findings of CNS though it failed to recover the virus from the brain, lungs, spleen and kidneys.

The results observed in the biting experiment on mice with the mosquito collected in nature in the five years from 1938 to 1942 in Okayama are summerized in Table 2. Experiments were chiefly done by the mosquito biting the mice but some experiment in November and December 1939 and during the period from January to June 1940 were made by the intracerebral inoculation into the mice with the emulsion prepared from the mosquito collected in nature. It is difficult to evaluate the positive isolation of Japanese $B$ encephalitis virus by using the mouse since the normal looking mouse may be seldom 
already infected as mentioned obove and the positivity of virus isolation may reflect chiefly the efficiency of the test for virus. Furthermore it is very important to know how often the normal looking mouse may be infected in Japan.

Anyway there is no crucial evidence concerning our newly isolated viruses in their origin in the mosquito collected in nature. Keeping it in mind the following points may be suggested on our results. Total number of mice applied for the experiment each year were 990, 1087, 1812, 794 and 698 among which 7, 13, 2. none and 4 mice respectively were found infected following exposure to the mosquito. It is to be noted that the positive isolation of the virus took place exclusively in the summer season and always failed in the cooler months. Number of mosquito infested per a mouse in the biting experiment was found naturally large in the warmer season and few during the cooler months as shown in Table 2. It is of interest further to note that the positive isolation of the virus among mosquitoes in nature always was observed 1 to 3 weeks prior to the outbreak of the epidemic as reported in 1938 and 1939. In other words the isolation of the virus is chiefly limited to the short time in earlier stage and hard in the later stage of the epidemic as mentioned by Hammon except 1939. These results may give us some suggestion to find the virus reservoir in nature. It should be, however, kept in mind that the negative isolation of the virus does not mean that the mosquito is absolutely free from the virus. The positive isolation, even if seldom, of the virus in the later stage of epidemic may represent that the cease of epidemic is not due to disappearance of the infectious mosquito.

Now the grade of the epidemic in each year observed for five years from 1938 to 1942 is represented by following signs, ++ when 150-200 cases were reported in one year, + when 100-150 cases, \pm when 50-100 cases and - when below 50 cases and the positivity rate of the virus isolation in each year in the same period from the mosquito in nature is shown in the proportion of the number of infected mice to the total mice undergone the biting experiment during the period from July to September. The positivity rate in each year mentioned above may be read as $2.0 \%, 2.5 \%, 0.2 \%, 0 \%$ and $0.6 \%$ respectively. The comparison of the grade of epidemic with the positivity rate of the virus isolation from the mosquito in nature is tabulated in Table 3. From this Table we can easily understand that there is some parallelism between the actual number of the reported human cases and the positivity rate of the virus isolation from the mosquito in nature.

With regard to the mosquito employed for the biting experiment on mice during the period from July to September in the five years the proportion of the number of mice, in which symptoms have actually developed, to that of mosquito which have bitten mice during the same period is shown as followed, 7 mice having been found positive with 2.726 mosquitoes in 1938, 13 mice with 2,898 mosquitoes in 1939, 2 mice with 3,552 mosquitoes in 1940, none of mouse with 1,606 mosquitoes in 1941 and 4 mice with 6.692 mosquitoes in 1942 (Table 2). Number of mosquito which was required mathematically to produce the disease in mice was understood to have been 389 mosquitoes in 1938, 233 in 1939, 1776 in 1940, unknown in 1941 and 1.673 in 1942 . These results may be under- 
stood that the larger the epidemic occurred the more the virus carrying mosquitoes have been found. As regards species of the mosquito which has produced encephalitis in mice on the biting experiment Culex tritaeniorhynchus is undoubtedly a virus carrying mosquito.

From the foregoing experiment it can be said that the grade of epidemic seems to be governed by the infectivity of the mosquito in nature as Mitamura mentioned (7) and that it is suggested by the fact that the virus is isolated from the mosquito only during the summer season to criticize further the mosquito how to be infected and the possibility with which mosquitoes become infected not by trans ovary infection of the virus, but there may be some reservoir of Japanese $B$ encephalitis virus in endemic area which gives the virus to the mosquito in the summer season.

\section{Conclusion}

Experimental study on the seasonal fluctuation of the mosquitoes and the positivity rate of the Japanese B encephalitis virus isolation from these mosquitoes was carried out during the period from May to early December 1942 in Okayama City. It was observed that the mosquito increases in number at the end of May, reaches a sharp top peak at the middle of July and then decreases rapidly towards the end of the same month. The total number of the mosquito collected in 177 working days in 1942 in nature were 6,033 among which Culex pipiens var. pallens was found $64.62 \%$ of the total, and Culex tritaeniorhynchus $32.3 \%$. The seasonal occurrence of the mosquito in Okayama consists of chiefly both species of mosquito. The remaining mosquitoes ( 3 per cent of the total) consist of various other species of mosquito.

Culex pipiens var. pallens has been found throughout the year and increased in number during the period from the end of June to early July at the maximum. Culex tritaenoiorhynchus has appeared in early June to make a sharp top peak at the middle of July and was collected till the first half in October.

More than 90 per cent in the number of mosquito collected as a whole at the socalled "Yamada's peak" at the middle of July was Culex tritaeniorhynchus.

All mosquitoes collected alive were employed in the biting experiment for the virus isolation. The biting experiment has been performed with 515 mosquitoes collected in nature on 181 mice but all the experiments failed to isolate the virus. And another experiment has been carried out with the mosquito collected at both the nurse dormitory and our dormitory Okayama Medical College to see if any of them may have been infected with Japanese B encephalitis virus by means of the feeding on mice. The total number of the mosquitoes collected at both dormitories above was 6,314 which were bred in 50 cages. These mosquitoes consisted of chiefly Culex tritaeniorhynchus and part of them Culex pipiens var. pallens and a few Anopheles hyrcanus sinensis and Aedes group. The total number of the mice bitten by the mosquito was 517. Among them one mouse having been bitten by 46 Culex tritaeniorhynchus collected on August 11 has developed typical symptoms, and the three other mice being bitten by mosquitoes, chiefly Culex tritaeniorhynchus collected on August 9, 15 and and 19, although they did not show 
a typical encephaltis symptom at the first generation, have developed a encephalitis on the second generation by intracerebral passage. These four virus strains have been identified by means of the neutralization test with Japanese B encephalits virus. Then it can be said that the isolation of the virus from the mosquito in nature was successful during a short period limited to about ten days.

Another trial of isolation of the virus from the autopsy materials of an human case has resulted in negative.

The results obtained during five years from 1938 to 1942 , on the positivity rate of the virus isolation from the mosquito collected in Okayama city were summarized and discussed on the relation to the grade of epidemic.

It may be understood that there is some parallelism between the grade of epidemic and the infectivity of the mosquito collected in nature. The positive isolation of the virus from the mosquito was. seen in the summer season especially 1 to 3 weeks prior to the outbreak of epidemic, while it remained negative during the cooler season in spring, autumn and winter. It is suggested that there can possibly be some other reservoir of the virus besides the mosquito, and that the virus does not be transfered by trans ovary infection. The cease of epidemic does not mean the disappearance of infected mosquito because the virus was hardly isolated from the mosquito collected in nature at the later stage in epidemic.

\section{REFERENCES}

1) Mori, K., Fukumi, H., Kumazawa, Y., Asida, M., Nagahata, K., Kageyama, H., Seki, O. and Akimoto, S.: Seasonal occurrence of mosquito in Okayama city in summer 1937. Tokyo Iji Sinsi, 62, 810-811, 1938 (in Japanese).

2) Mitamura, T., Kitaoka, M., Watanabe, $\mathrm{S}$ and Tenjin, S. : Inapparent infection with Japanese B encephalitis in 1938. Seasonal fluctuation of neutralizing antibody in serum. Relation of epidemic to inapparent infection and neutralizing antibody in serum. Tokyo Iji Sinsi, No. 3143, 1871-1877, 1939 (in Japanese).

3) Mitamura, T., Kitaoka, M., Watanabe, S., Iwasaki, T., Tenjin, S., Isikawa, I., Jo, K., Yosida, H., Yoshimatsu, D., Warabioka, K., Shimizu, M. and Watanabe, T.: Seasonal occurrence of mosquito in Okayama city in 1938. On infectivity of the mosquito. Nipponigakn oyobi Kenkohoken, No. 3208, 743-745, 1940 (in Japanese).

4) Mitamnra, T., Kitaoka, M., Watanabe, S., Tenjin, S., Mizuhara, K., Nakazato, A. and Shimizu, M. : Seasonal occurrence of mosquito in Okayama city from November 1941 to October 1942. On infectivity of the mosquito. Relation of epidemic to infectivity of mosqnito. Nipponigaku oyobi Kenkohoken, No. 3270, 354-357, 1942 (in Japanese).

5) Mitamura, T. and Kitaoka, M. : unpublished data.

6) Kawamura, R., Kasahara, S., Miyata, T., Ueda, M. and Yamada, R. : Isolation of virus from the mouse bought from a animal dealer. 'Kitasato Arch, Exp. Med., 17, 38-45, 1940.

7) Mitomura, T., Kitaoka, M., Watanabe, S., Tenjin, S., Kihara, K., Nakazato, A. and Shimizu, M. : Seasonal occurrence of mosquito in Okayama city from November 1939 to February 1941. On infectivity of the mosquito relation of epidemic to infectivity of mosquito. The report of the 15th Rengo-biseibutu-gakkai, 151-158, 1941.

8) Hammon, W. McD., Tigertt, W. D., Sather, G. and Schenker, H.: Isolation of Japanese B encephalitis virus from naturally infected Culex tritaeniorhynchus collected in Japan. Amer.J. Hyg., 50, 51-56, 1949.

9) Kitaoka, M. and Baba, S.: Japanese B encephalitis virus and the other unknown virus recovered from the normal mice supplied by the mouse dealer in 1948. Nihonnoen Kenkyukyogikai, 247-248, 1948 (in Japanese). 
Table 1

Seasonal occurrence of mosquito in Okayama City 1942

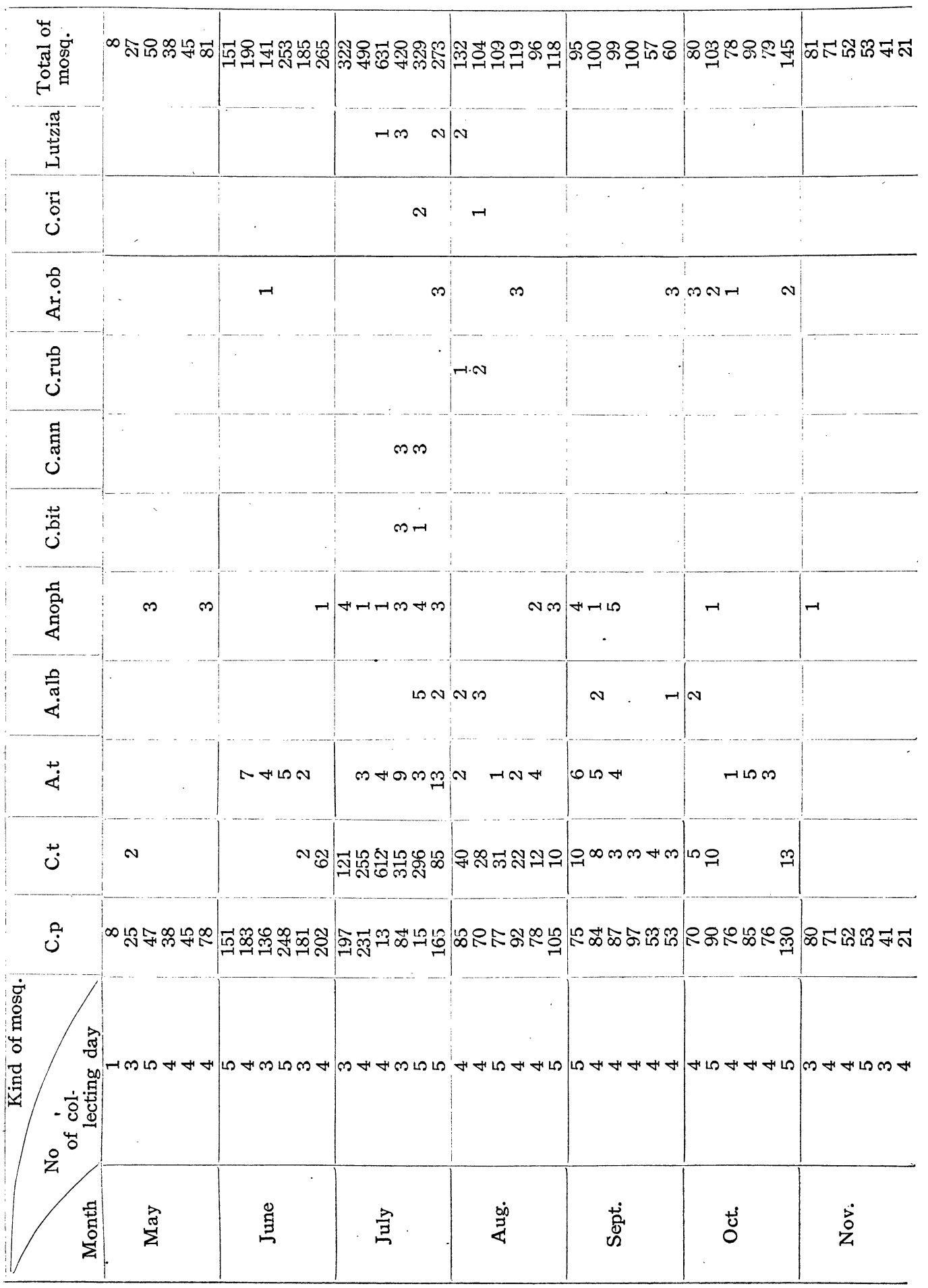




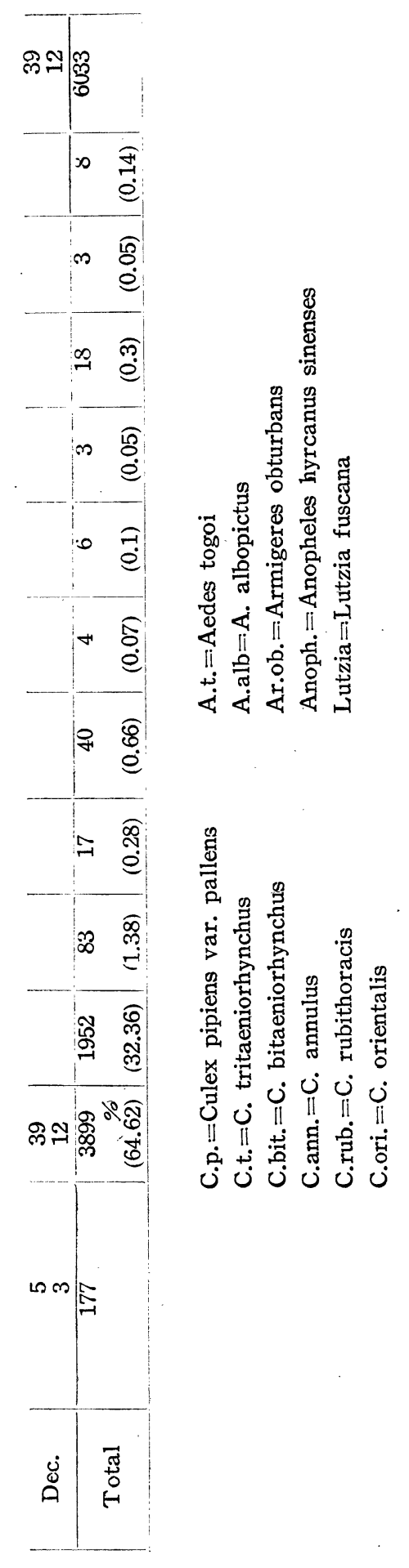


Table 2

Biting experiment with mosquito collected in nature in Okayama in mice during the period from 1938 to 1942

\begin{tabular}{|c|c|c|c|c|c|c|c|c|c|c|c|c|c|c|c|}
\hline \multirow{2}{*}{ ᄅे } & & & & \multicolumn{3}{|c|}{ - 0 \%ొ } & \multicolumn{2}{|c|}{ O|R } & m & \multicolumn{2}{|c|}{ olల్ల } & $\underset{r}{\stackrel{0}{-}}$ & \multicolumn{2}{|c|}{$0 \mid \infty$} & $\stackrel{0}{-i}$ \\
\hline & & & & \multicolumn{3}{|c|}{ - O|l\$ } & \multicolumn{2}{|c|}{$0 \mid \not R$} & ָ. & \multicolumn{2}{|c|}{ 이고 } & $\stackrel{0}{-i}$ & \multicolumn{2}{|c|}{ 이 } & i \\
\hline & & & & \multicolumn{2}{|c|}{ 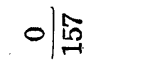 } & $\stackrel{+}{-}$ & \multicolumn{2}{|c|}{$\circ \mid \infty 8$} & $\vec{r}$ & \multicolumn{2}{|c|}{ - $\mid \ddot{m}$} & $\stackrel{0}{-i}$ & \multicolumn{2}{|c|}{ 이옥 } & $\stackrel{\circ}{-i}$ \\
\hline 0 & & & & \multicolumn{2}{|c|}{ 이요 } & $\stackrel{\circ}{+}$ & \multicolumn{2}{|c|}{ OIN } & in & \multicolumn{2}{|c|}{$0 \mid 0$} & $\stackrel{0}{-i}$ & \multicolumn{2}{|c|}{ 이오 } & - \\
\hline \multirow{2}{*}{$\begin{array}{l}\text { 葛 } \\
\text { 心 }\end{array}$} & & & & \multicolumn{2}{|c|}{ 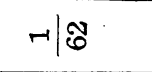 } & $\begin{array}{l}0 \\
\text { Lे }\end{array}$ & \multicolumn{2}{|c|}{ 이카 } & $\begin{array}{l}0 \\
\text { ง }\end{array}$ & \multicolumn{2}{|c|}{ o| } & $\stackrel{m}{-}$ & \multicolumn{2}{|c|}{ o惿 } & $\begin{array}{l}0 \\
\text { Ni }\end{array}$ \\
\hline & ols & & ๓ं & \multicolumn{2}{|c|}{$m / 8$} & $\stackrel{N}{\oplus}$ & \multicolumn{2}{|c|}{ ०) } & $\begin{array}{l}10 \\
\text { i }\end{array}$ & \multicolumn{2}{|c|}{ 임 } & ri & \multicolumn{2}{|c|}{ 이요 } & 10 \\
\hline \multirow{2}{*}{ 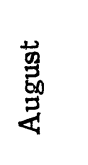 } & $N \mid$ & & $\ddot{m}$ & \multicolumn{2}{|c|}{ เ 1 읔 } & $\stackrel{m}{\stackrel{n}{*}}$ & \multicolumn{2}{|c|}{$\circ \mid \underset{\mathcal{N}}{\infty}$} & $\stackrel{\leftrightarrow}{\text { ò }}$ & $0 \mid$ & & นึ & 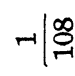 & & $\stackrel{\text { L }}{\ddot{m}}$ \\
\hline & +18 & & $\stackrel{0}{\circ}$ & $m \mid$ & & $\stackrel{\sim}{i s}$ & $N \mid$ & & $\stackrel{m}{\rightarrow}$ & 01 & & $\begin{array}{l}\infty \\
\dot{m}\end{array}$ & $m \mid \frac{\infty}{\sqrt{N}}$ & & ำ \\
\hline & -1 & & $\stackrel{m}{i}$ & -10 & & $\stackrel{0}{\circ}$ & $0 \mid$ & & $\hat{\sim}$ & 0 & & $\stackrel{0}{+}$ & 이콕 & & $\stackrel{?}{\circ}$ \\
\hline 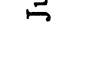 & ols & & $\stackrel{m}{+}$ & $0 \mid \varsigma$ & & $\stackrel{\infty}{+}$ & 0 & & $\stackrel{N}{m}$ & & & & 잋 & & is \\
\hline & $0 \mid i$ & & is & ols & & $\stackrel{8}{4}$ & .01 & & & $0 \mid$ & & $\hat{N}$ & $0 \mid 1$ & & $\stackrel{+}{\mu}$ \\
\hline 皇 & $0 \mid$ & & $\stackrel{\infty}{\infty}$ & $0 \mid$ & & $\stackrel{-1}{\text { งे }}$ & .01 & & & 이 & & $\stackrel{\circ}{\leftrightarrow}$ & $0 / 0$ & & $\stackrel{N}{m}$ \\
\hline$\geqslant$ & $0 \mid 8$ & & $\stackrel{m}{i}$ & $0 \mid 8$ & & $\stackrel{9}{-i}$ & .015 & & & ol & & $\overrightarrow{\hat{N}}$ & $0 \mid 0$ & & $\ddot{m}$ \\
\hline$\ddot{\Sigma}$ & 015 & & $\dot{0}$ & 01 & & $\stackrel{\infty}{-i}$ & .01 & & & 이 & & $\stackrel{\circ}{\text { N่ }}$ & & & \\
\hline$F$ & $0 \mid \delta$ & & $\stackrel{N}{N}$ & & & & . olt & & & 0 & & $\stackrel{\circ}{\circ}$ & & & \\
\hline$\frac{n}{4}$ & 이요 & & $\stackrel{\circ}{\text { i }}$ & & & & . 이 & & & & & & & & \\
\hline 융 & $0 \mid$ & & $\stackrel{0}{i}$ & & & & .015 & & & & & & & & \\
\hline$\sum_{\Sigma}^{\pi}$ & $0 \mid$ & & $\stackrel{0}{-}$ & & & & .01 & & & & & & & & \\
\hline ? & & & & & & & .01 & & & 이 & & $\stackrel{\circ}{-i}$ & & & \\
\hline 环 & & & & & & & .01 & & & 이 & & i. & & & \\
\hline & 0 & & & & & & .01 & & & 01 & & i & & & \\
\hline$\stackrel{0}{2}$ & $\triangleleft$ & & & & & & .01 & & & 이 & & 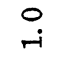 & & & \\
\hline 롫 & 4 & $\infty$ & 0 & $\varangle$ & $\infty$ & 0 & $\varangle$ & $\infty$ & $u$ & $\varangle$ & $\infty$ & 0 & $\varangle$ & $\infty$ & 0 \\
\hline zे & & 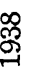 & & & ஜ্ণু & & & 윰 & & & 节 & & & ঙี & . \\
\hline
\end{tabular}




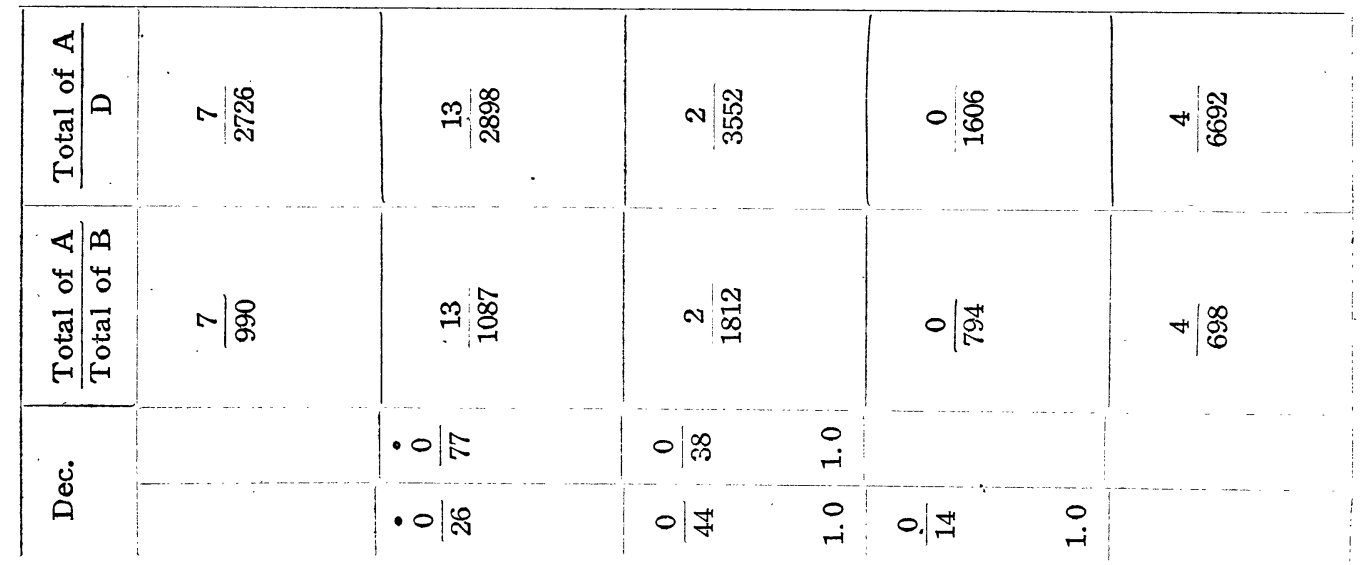

$\triangle \bigcirc$...each month devided into two, fore and latter halfs

-...inoculation with mosquito emulsion and the other on the biting experiment

A...no of infected mice

B...total no of mice bitten or inoculated with mosquito emulsion

C....averaged no of mosquitoes biting a mouse

D...total no of mosquitoes biting mice during the period from July to September

Table 3

Relationship between the outbreak of epidemic and the infectivity of mosquito in nature

\begin{tabular}{|c|r|r|r|r|r|}
\hline Year & 1938 & 1939 & 1940 & 1941 & 1942 \\
\hline No of infected mice & 7 & 13 & 2 & 0 & 4 \\
\hline Total no of bitten mice & 346 & 530 & 1040 & 512 & 621 \\
\hline Morbidity rate & $2.0 \%$ & $2.5 \%$ & $0.2 \%$ & 0 & $0.6 \%$ \\
\hline Grade of epidemic & + & $+(+)$ & - & - & \pm \\
\hline
\end{tabular}

Biting experiment with mosquito during the period from July to September 
Fig 1.

Seascnal occurrence of mosquito in Okayama City 1942

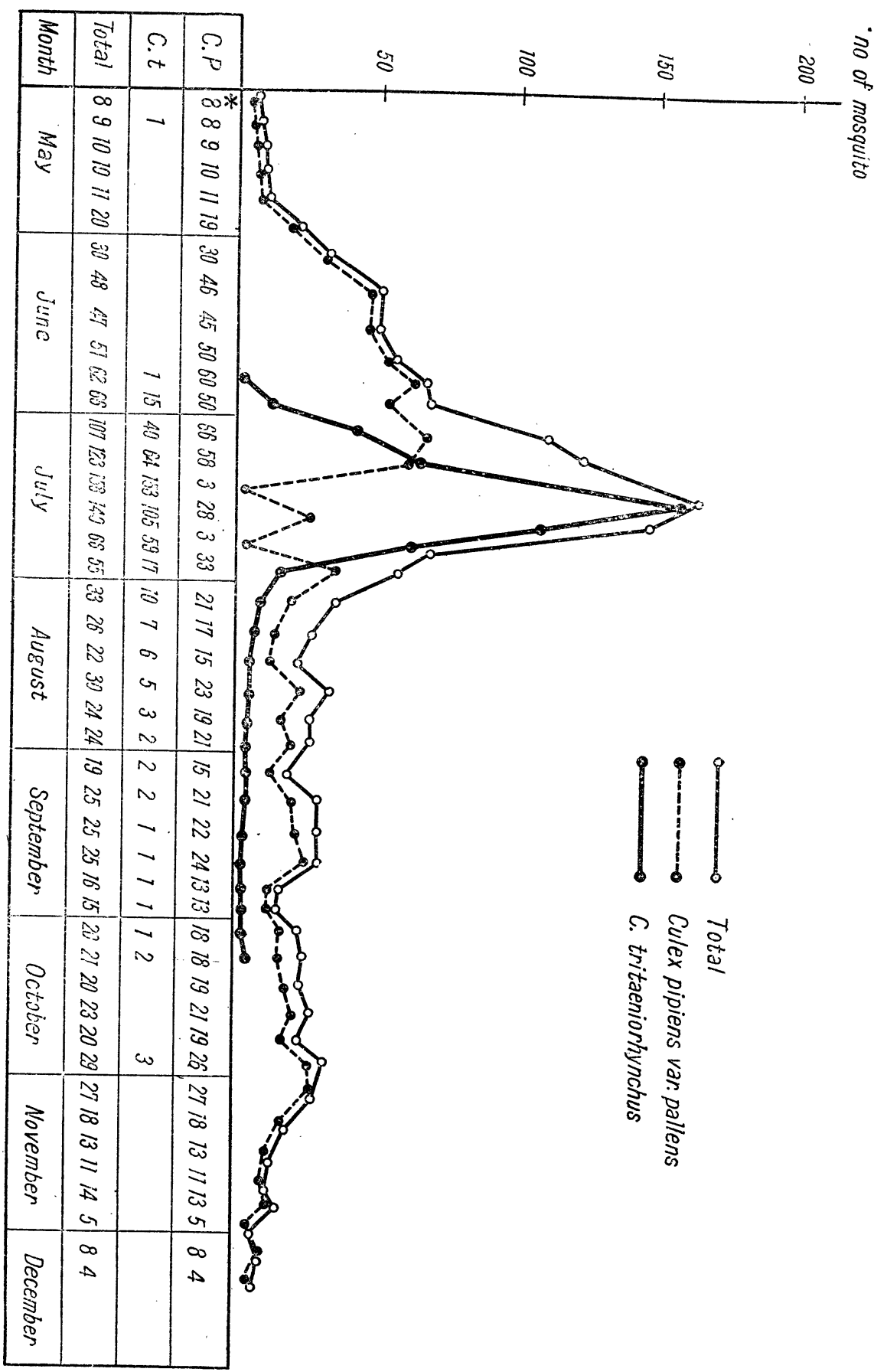

* Daily averaged number of mosquito collected. 